\title{
PERJANJIAN BARU DAN TEOLOGI
}

\author{
Alfonsus Ara*
}

\begin{abstract}
Abstrak
Perjanjian Baru bukanlah cabang dari teologi, tetapi sebagai akar, sumber, landasan dan otoritas tertinggi dalam berteologi. Berangkat dari penegasan ini, maka disimpulkan bahwa: pertama, sesungguhnya penulis Kitab Suci Perjanjian Baru tidak berteologi (teologi ilmiah). Mereka hanya menulis dan meneruskan (laporan, rencana) Wahyu Allah yang terpenuhi dalam diri Yesus Kristus (teologi dasar); kedua, Perjanjian Baru adalah inti dari Wahyu Allah sendiri, bukan bagian dari teologi.
\end{abstract}

Kata-kata Kunci: Perjanjian Baru, teologi, wahyu, sistem, sistematisasi, agape, narasi, ortodoksi, tradisi, inkulturasi, apostolic

\section{Hantaran}

Inti pembahasan tulisan ini terfokus pada dua hal fundamental, yaitu: pertama, "Teologi Perjanjian Baru" dan pelbagai argumen tertulis yang tertuang dalam aneka bentuk karya serta relevansinya bagi kaum beriman Kristiani untuk memahami landasan imannya; ${ }^{1} k e d u a$, usaha untuk merancang kembali dimensi ilmiah yang terkandung di dalam ide-ide dasar dari tulisan-tulisan Perjanjian Baru. ${ }^{2}$ Langkah ini dinilai

1 R. Bultmann, Teologia del Nuovo Testamento, Brescia 1985; C. H. Dodd, La Predicazione apostolica e il suo sviluppo, Brescia 1973; Oscar Cullmann, Il Mistero della Redenzione nella Storia, Bologna 1966; H. Conzelmann, Teologia del Nuovo Testamento, Brescia 1972; L. Goppet, La Teologia del Nuovo Testamento, Brescia 1982, 1983; J. Jeremias, Teologia del Nuovo Testamento, I: La Predicazione di Gesù, Brescia 1976; G. Segalla, Panorama teologico del Nuovo Testamento, Brescia 1987.

2 Teologi Perjanjian Baru merupakan spesifikasi dari Teologi Biblis: Teologi yang membatasi diri untuk melukiskan ajaran iman sebagaimana terkandung di dalam Kitab Suci. Karakter primordial dari teologi tersebut adalah kesetiaan yang teguh kepada pesan penginjil. Secara mendalam, Teologi Biblis merupakan sebuah disiplin ilmu yang merujuk pada sejarah (Vilanova, E. Vilanova, Storia della teologia cristiana, Borla, Roma, vol I, 1991, vol. II, 1995, in AA. VV. (Istituto Patristico Augustinianum), Stroria della Chiesa, Piemme, Casale Monferrato, vol. I, 1993 \& vol. III, 1994, 28). 
sebagai sebuah model pencarian yang adekuat, walaupun kerap membingungkan.

Sesungguhnya, dalam lingkup pengertian khusus, tidak ada "Teologi Perjanjian Baru", sebab tiada seorang pengarang pun yang mampu mensistematisasikan Sabda Allah (Wahyu) secara padu dan mendalam. Berkat inspirasi Roh Ilahi, para penulis Kitab Suci diberdayakan untuk membahasakan Sabda Allah ke dalam bahasa manusia. Mereka merekam dan menuliskan aneka peristiwa keselamatan yang dinyatakan dalam peristiwa (tindakan) sejarah, menggali maknanya, menerjemahkannya ke dalam bahasa manusia setempat dan memperdalam makna sastra untuk memahami konteks dan arti yang sesungguhnya.

Ditegaskan bahwa, "Pengarang Perjanjian Baru tidak berteologi". Satu tindakan satu fundamental yang mereka lakukan adalah sesetia mungkin menuliskan dan meneruskan (laporan, rencana) Wahyu Allah yang terpenuhi dalam diri Yesus Kristus sebab Dia adalah Sabda Kekal Allah yang menjelma menjadi Manusia. Sasaran mereka adalah menyingkapkan "Inti Kebenaran Allah" dalam diri Yesus Kristus supaya diterima, dihayati dan dihidupi oleh manusia.

Sasaran ini tertuang jelas dalam pernyataan Rasul Yohanes di awal tulisannya:

$<<$ Apa yang telah ada sejak semula, yang telah kami dengar, yang telah kami lihat dengan mata kami, yang telah kami saksikan dan yang telah kami raba dengan tangan kami tentang Firman hidup - itulah yang kami tuliskan kepada kamu. Hidup itu telah dinyatakan, dan kami telah melihatnya dan sekarang kami bersaksi dan memberitakan kepada kamu tentang hidup kekal, yang ada bersama-sama denga Bapa dan yang telah dinyatakan kepada kami. Apa yang telah kami lihat dan yang telah kami dengar itu, kami beritakan kepada kamu juga, supaya kamu pun beroleh persekutuan dengan kami. Dan persekutuan kami adalah persekutuan dengan Bapa dan anak-Nya, Yesus Kristus >> (I Yoh 1,1-3). 
Dalam merancang kembali Sejarah Teologi, para teolog mengalami kesulitan untuk memaparkan secara luas dan mendalam mengenai cakupan dan muatan Teologi Biblis. Langkah sederhana yang dilakukan adalah mendasarkan rancangan kerja mereka pada 'Naskah-naskah Suci". Naskah-naskah tersebut dijadikan "acuan", "obyek" atau "materi utama" yang menentukan arah kerja mereka dalam merumuskan (memproduksi) gagasan teologis yang baru. Namun, karya permenungan mereka berakar dalam inti warta Kitab Suci itu sendiri.

Langkah ini dinilai sepadan dengan pemahaman asali 'teologi' sebagai aktivitas ilmiah (pengetahuan) manusia dalam menghimpun dan menjelaskan inti misteri Wahyu Ilahi dalam terang iman supaya bisa dipahami dan dihayati oleh kaum beriman. Apabila makna dan muatan teologi ditempatkan dalam pemahaman asali ini, maka diakui keberadaan "teologi biblis" sebagai sebuah disiplin ilmu, seperti teologi dogmatik, teologi moral, teologi pastoral, teologi misi, dll. Walaupun demikian, tetap diakui bahwa tiada satupun dari disiplin ilmu ini yang menjadi bagian dari Wahyu Ilahi. Penegasan ini didasarkan pada dua alasan hakiki: pertama, disiplin-disiplin ilmu ini tidak mampu mensistematisasikan Wahyu Allah; kedua, disiplin-disiplin ilmu init dan ilmu-ilmu manusiawi lainnya hanya mampu melakukan pendekatan rasional terhadap Wahyu Allah yang menduduki tempat terpenting dalam Tradisi Iman Gereja dengan menggunakan metode hermeneutik agar inti iman Gereja bisa dipertanggungjawabkan dengan nalar manusia beriman.

Berdasarkan kenyataan ini, maka dapat ditegaskan bahwa inti minat Teologi terhadap Kitab Suci terfokus pada muatan iman, yaitu misteri Wahyu Allah dalam Perjanjian Lama dan Perjanjian Baru, bentuk sastra dan konsep-konsep yang terkandung di dalamnya. Bukubuku yang memotivasi para teolog untuk mengadakan studi: mencari, memperdalam dan menafsir inti pemahamannya adalah Naskah Suci, Kitab Suci, Sabda Allah sendiri.

Teologi Biblis merupakan sebuah disiplin ilmu yang relatif baru sebab masih mencari forma, obyek dan metodenya sendiri. ${ }^{3}$ Pada abad ke XX beberapa tokoh berusaha merumuskan dan menentukan arah atau sasaran Teologi Biblis: Rudolf Bultmann dengan sasaran

${ }^{3}$ Vilanova, Storia della Teologia Cristiana..., 29. 
utamanya "Pe-Mistis-an" (Demitologi) Kitab Perjanjian Baru; Oscar Culman terfokus pada "Sejarah Keselamatan" dan Kasemmann lebih terorientasi pada dimensi "Eskatologi". Walaupun demikian, hanya satu pertanyaan fundamental yang harus senantiasa direnungkan, yaitu: "Siapa yang menggali traktat Teologi Dogmatik saat ini, bukan siapa yang berkisah dengan Sejarah Teologi!

Oleh karena itu, perhatian kita tidak dipusatkan pada Teologi Biblis, tetapi pada lingkup budaya dan pengaruhnya bagi Teologi Kristen. Walaupun demikian, patut diakui bahwa di antara lingkup budaya yang sangat berpengaruh dalam Teologi Kristen, Perjanjian Baru menduduki tempat termulia.

Setelah mempublikasikan karya termasyurnya yang berjudul "Pe-Mistis-sasian": Perjanjian Baru dan Mitologi, Rudolf Bultmann memaparkan hubungan antara Injil dan Mitologi. Secara efektif, persoalan terpenting yang harus digali oleh para ekseget Kitab Suci, Teologi Biblis, Teologi Dogmatik dan kaum Kristiani umumnya adalah mampu membedakan antara bentuk dan muatan kerygma (pewartaan) serta memperlihatkan hubungannya bagi kaum beriman.

Mengacu pada aspek ini, maka persoalan terpenting terfokus pada Sejarah Teologi. Pencarian Sejarah Teologi bergerak di antara dua titik penting: 1) Inti Wahyu yang terkandung di dalam Perjanjian Baru; 2) Forma Teologi dari setiap tulisan Perjanjian Baru.

\section{Inti Wahyu Perjanjian Baru: Agape (cinta agapik)}

Pada prinsipnya, inti Wahyu Perjanjian Baru hanya mengambil, melengkapi dan menyempurnakan seluruh tema Wahyu Perjanjian Lama, yaitu menyempurnakan lukisan Wajah Allah Perjanjian Lama.

$<<$ Setelah pada zaman dahulu Allah berulang kali dan dalam pelbagai cara berbicara kepada nenek moyang kita dengan perantaraan nabi-nabi, maka pada zaman akhir ini Ia telah berbicara kepada kita dengan perantaraan Anak-Nya, yang telah Ia tetapkan sebagai yang berhak menerima segala yang ada. Oleh Dia Allah telah menjadikan alam semesta>> (Ibrn 1,1-2). 
Keabsolutan Allah Perjanjian Lama memperoleh lukisan yang sempurna dalam Triplice Wajah Allah (prosopon, persona): Bapa, Putera dan Roh Kudus. Allah mewahyukan diri-Nya sebagai Cinta: "Allah adalah cinta: Deus caritas est (I Yoh 4,16). Cinta berada dalam dan mempersatukan Bapa, Putera dan Roh Kudus.

Di satu pihak, pewahyuan misteri trinitarian dalam Perjanjian Baru dipandang sebagai integrasi sederhana dari inti ajaran iman Perjanjian Lama (bdk. Mrk 10,28; 12,29); namun, di pihak lain ditegaskan bahwa puncak pewahyuan diri Allah yang Esa dan Trinitas justru terpenuhi dalam Perjanjian Baru: "Semua bentuk pewahyuan Perjanjian Lama terpenuhi secara definitif dalam diri Yesus, Allah yang menjelma menjadi manusia. Dia adalah "Dasar" dan "Puncak" semua pewahyuan Allah kepada Umat Perjanjian. Allah orang Kristen bukanlah Allah yang menutup diri dalam kekudusan-Nya sebagaimana diperkenalkan kepada Bangsa Yahudi; Allah orang Kristen adalah Allah hidup dalam diri-Nya sendiri dengan membina suatu dialog yang intensif dan mendalam dengan semua ciptaan-Nya hingga Allah rela memberikan diri-Nya sebagai rahmat dan berkat bagi manusia melalui peristiwa inkarnasi Sang Putera.

Dari cinta trinitarian yang tidak terbatas tercipta (berasal) Malaikat, manusia dan karya keselamatan bagi manusia: Bapa sungguh-sungguh mencintai manusia sehingga Dia mengutus PuteraNya yang Tunggal ke dunia untuk menyelamatkan mereka dari kuasa dosa dan masuk dalam persekutuan hidup Ilahi dengan-Nya.

$<$ Dalam hal inilah kasih Allah dinyatakan di tengah-tengah kita, yaitu bahwa Allah telah mengutus Anak-Nya yang tunggal ke dalam dunia, supaya kita hidup oleh-Nya. Inilah kasih itu: Bukan kita yang telah mengasihi Allah, tetapi Allah yang telah mengasihi kita dan yang telah mengutus Anak-Nya sebagai pendamaian bagi dosa-dosa kita (...). Jikalau Allah sedemikian mengasihi kita, maka haruslah juga kita saling mengasihi. Tidak ada seorang pun yang pernah melihat Allah. Jika kita saling mengasihi, Allah tetap di dalam kita dan kasih-Nya sempurna di dalam kita. Demikianlah kita ketahui, bahwa kita tetap berada di dalam Allah dan Dia di dalam kita: Ia telah mengaruniakan kita mendapat bagian dalam Roh-Nya. Dan kami telah melihat dan bersaksi, bahwa Bapa telah mengutus Anak-Nya menjadi Juruselamat dunia. Barangsiapa mengaku, bahwa Yesus adalah 
Anak Allah, Allah tetap berada di dalam dia dan Dia di dalam Allah. Kita telah mengenal dan telah percaya akan kasih Allah kepada kita>> (I Yoh 4,9-16).

Cinta Bapa dan Putera dalam persekutuan Roh Kudus nyata dalam penjelmaan, kehidupan, sabda dan karya, Yesus, Sang Putera. Setelah menunaikan karya Perutusan-Nya, Sang Putera kembali kepada Bapa-Nya dan mengutus Roh-Nya untuk menolong, menghibur dan membimbing Gereja-Nya.

$<$ Aku akan minta kepada Bapa, dan Ia akan memberikan kepadamu seorang Penolong yang lain, supaya Ia menyertai kamu selama-lamanya, yaitu Roh Kebenaran. Dunia tidak dapat menerima Dia, sebab dunia tidak melihat Dia dan tidak mengenal Dia. Tetapi kamu mengenal Dia, sebab Ia menyertai kamu dan akan diam di dalam kamu>> (Yoh 14,16-17).

Sebagai wujud inkarnasi cinta Allah, Yesus memberikan kesaksian tentang cinta dan Dia adalah Inti Cinta itu sendiri yang menjelma menjadi manusia untuk mewartakan Injil Kerajaan Allah kepada orang-orang tertindas, terbuang, tertekan, para pendosa dan orang-orang yang sederhana. Dia melakukan banyak mukjizat untuk memperlihatkan kuasa cinta Allah kepada kaum miskin, orang sakit, orang yang kerasukan roh jahat dan orang-orang yang terbuang dari pusat kehidupan. Dia memberikan kehidupan-Nya sendiri kepada kita, manusia pendosa untuk memperdamaikan kita dengan Allah serta mencurahkan cinta-Nya sendiri ke dalam hati kita. Dia mengorbankan diri-Nya untuk kita sebagai "Anak Domba Allah"; menghapus dosadosa kita dan menghantar kita untuk ambil bagian dalam kehidupanNya sendiri: "Aku datang supaya kamu mempunyai hidup, dan mempunyainya dalam kelimpahan" (Yoh 10,10).

Karena cinta-Nya yang meluap, Dia tidak akan pernah meninggalkan kita di saat musuh-musuh-Nya menghukum-Nya hingga ke ambang kematian dan sampai Bapa-Nya memanggil-Nya kembali ke pangkuan-Nya di surga; duduk di sisi kanan Sang Bapa. Dia selalu bersama kita di dalam dan melalui sakramen cinta-Nya, Ekaristis Kudus. Melalui sakramen yang menakjubkan dan dasyat dengan kekuatan cinta-Nya, "Pucak dan Sumber" keberadaan kaum Kristiani, Kristus menderita dan dimuliakan, hadir dalam wujud yang baru dan real di tengah kehidupan manusia, di setiap waktu dan 
tempat untuk mendamaikan kita dengan Allah dan sesama serta memenuhi diri kita dengan kehidupan Ilahi-Nya. Ekaristi Kudus merealisasikan kesatuan kita dengan Kristus dan Allah Trinitas. Melalui rahmat yang mengalir dari Ekaristi Kudus, Roti kehidupan dan Piala tebusan Ilahi, Kristus melampaui dan mengalahkan kecenderungan hati kita di semua bangsa dan di setiap zaman sehingga kita semua menjadi anggota Tubuh Mistik-Nya, Gereja, dan keluargaNya sendiri. Ekaristi menjadi momen yang sangat berarti bagi Kristus untuk merealisasikan kedalaman cinta-Nya bagi diri dan kehidupan kita: Ekaristi adalah memoriale salutis (kenangan akan keselamatan), yang dasyat, menakjubkan dan kekal.

Seluruh kehidupan dan karya-Nya bersama para murid-Nya dilandaskan pada kekuatan cinta-Nya: Cinta adalah "Perintah Baru" yang diberikan-Nya kepada para pengikut-Nya:"Aku memberikan perintah baru kepada kamu, yaitu supaya kamu saling mengasihi, sama seperti Aku telah mengasihi kamu demikian pula kamu harus saling mengasihi" (Yoh 13,34); "Hukum Utama”, Perintah Tertinggi:

"Kasihilah Tuhan, Allahmu, dengan segenap hatimu dan dengan segenap jiwamu dan dengan segenap budimu. Itulah hukum yang terutama dan yang pertama. Dan hukum yang kedua, yang sama dengan itu, ialah: kasihilah sesamamu manusia seperti dirimu sendiri. Pada kedua hukum inilah tergantung seluruh hukum Taurat dan kitab para nabi" (Mat 22,37-40).

Di dalam cinta terkandung seluruh perintah moral: "Seluruh hukum Taurat tercakup dalam satu firman ini, yaitu kasihilah sesamamu manusia seperti dirimu sendiri" (Gal 5,14).

$<$ Hendaklah kamu saling mengasihi. Sebab barangsiapa mengasihi sesamanya manusia, ia sudah memenuhi hukum Taurat. Karena firman: jangan berzinah, jangan membunuh, jangan mencuri, jangan mengingini dan firman lain mana pun juga, sudah tersimpul dalam firman ini, yaitu: Kasihilah sesamamu manusia seperti dirimu sendiri! Kasih tidak berbuat jahat terhadap sesama manusia, karena kasih itu adalah kegenapan hukum Taurat" (Rom 13, 8-10). 
Cinta kasih merupakan nilai absolut yang mendasari semua nilai kehidupan manusia; tanpa cinta kasih semua nilai menjadi steril (gersang, mandul). Cinta kasih akan menetap dan menguatkan iman dan harapan:

"Kasih tidak berkesudahan; nubuat akan berakhir: bahasa roh akan berhenti; pengetahuan akan lenyap. Sebab pengetahuan kita tidak lengkap dan nubuat kita tidak sempurna. Tetapi jika yang sempurna tiba, maka yang tidak sempurna itu akan lenyap. Ketika aku kanak-kanak, aku merasa seperti kanak-kanak, aku berpikir seperti kanak-kanak. Sekarang sesudah aku menjadi dewasa, aku meninggalkan sifat kanak-kanak itu. Karena sekarang kita melihat dalam cermin suatu gambaran yang samarsamar, tetapi nanti kita akan melihat muka dengan muka. Sekarang aku hanya mengenal dengan tidak sempurna, tetapi nanti aku akan mengenal dengan semprna, seperti aku sendiri dikenal. Demikianlah tinggal ketiga ha lini, yaitu iman, pengharapan dan kasih dan yang paling besar di antaranya ialah kasih" (I Kor 13,8-13).

Di dalam diri dan kehidupan Yesus, kasih menduduki tempat pertama dan paling utama. Seluruh kehidupan-Nya diabdikan untuk cinta dan mencintai: "Mencintai Allah dan sesama". Cinta merupakan dasar yang menggerakkan seluruh kehidupan-Nya, sehingga Dia tidak gentar menghadapi aneka tantangan duniawi. Karena cinta, Dia tidak membiarkan kepicikan hukum lama yang tertulis di log batu dan Tradisi mengekang kehidupan manusia; karena cinta Dia gigih berjuang untuk mematahkan rantai diskriminasi sosial; membebaskan kaum miskin dan terbuang dari ancaman orang-orang yang berkuasa, dari kekerasan musuh-musuhnya....hingga rela mengorbankan nyawaNya di kayu salib yang hina.

Dari titik ini, kita dituntut untuk menggali, menemukan dan menyingkapkan inti Kitab Perjanjian Baru sebagai dasar bagi setiap permenungan teologis, yaitu inti agape. Seluruh Perjanjian Baru merupakan "Madah Cinta": Cinta adalah kekuatan dasar yang mempersatukan Tiga Pribadi Ilahi. Seluruh kehidupan Tiga Pribadi Ilahi lahir dari Tiga Relasi Cinta: Bapa, Putera dan Roh Kudus (Pengantin). Cinta Trinitas menjadi akar, asal dan dasar pilihan Israel; dasar penjelmaan Sang Sabda Kekal dan landasan keselamatan umat manusia. Kebaruan kekuatan cinta yang dibangun Kristus dalam 
fondasi Gereja-Nya bertujuan mengaktualisasikan relasi Trinitarian dengan manusia dan relasi di antara manusia. Saluran cinta adalah sakramen; di dalam dan melalui daya sakramental rahmat Allah tercurah ke dalam Gereja-Nya. Gereja mengemban misi ilahi untuk menyalurkan kehidupan kekal kepada manusia. Etika kristen, secara esensial, merupakan etika agape, etika cinta yang bergerak menuju Allah dan sesama.

Banyak benang bisa mempersatukan semua misteri yang diwahyukan Allah kepada manusia Perjanjian Lama dan Perjanjian Baru. Namun satu benang yang bisa mempersatukan semua tanpa perbedaan adalah benang cinta, benang agapik. Inti benang ini akan mencapai sesuatu yang baik untuk mengindividualisasikan atau menspesifikasikan keutamaan wahyu Kristiani, konsekuensinya juga pada teologi kristen. ${ }^{4}$

\section{Bentuk-bentuk Teologi dalam Tulisan Perjanjian Baru}

Pencarian bentuk-bentuk teologi yang terkuak dari tulisan-tulisan Perjanjian Baru tidak dimaksudkan untuk menegaskan keberadaan Perjanjian Baru sebagai cabang dari teologi, tetapi sebagai akar, sumber, landasan dan otoritas tertinggi dalam berteologi. Upaya penggalian ini mutlak dilakukan untuk menemukan inti kebenaran dan nilai "hakiki" dari Teologi Perjanjian Baru serta menegaskan bahwa Teologi Perjanjian Baru merupakan bagian dari Wahyu Ilahi, bukan bagian dari teologi.

Mengacu pada prinsip ini, maka harus ditegaskan bahwa argumen-argumen yang dipaparkan Yohanes dan Paulus tidak termasuk dalam kategori teologumeni atau opini seorang teolog, tetapi bagian dari Wahyu Allah yang satu dan sama.

$<<$ Elemen-elemen ini, secara langsung, memaparkan kehidupan di zaman para Rasul pada periode akhir sejarah kekristenan.

4 Untuk motivasi dalam kuliah Teologi Dogmatik (5 volume, Edisi Studi Dominikan, Bologna 1992-1994), maka kita memiliki cinta agapik sebagai prinsip pemersatu dalam keseluruhan diktat ini. 
Berkat kekuatan Roh Kudus, elemen-elemen ini membentuk "hanya" satu Wahyu yang eksplisit>>.5

Semua tema, muatan dan perkembangan Teologi Perjanjian Baru merupakan bagian dari tenunan Teologi Dasar, bukan hasil dari sebuah penafsiran (hermeneutik). Konsekuensi logis berkenaan dengan buah penelitian ini adalah sebagai berikut: "Peristiwa inkarnasi Logos Kekal Allah ke dalam logos manusiawi sebagaimana dilukiskan Perjanjian Baru diungkapkan dalam bahasa dan logika umum manusia serta merangkum semua kategori dan perkembangan khusus dalam lingkup teologis".

Mengacu pada hantaran ini, maka kita diajak untuk melihat elemen-elemen penting dari "Forma Teologi Perjanjian Baru":

\section{Bahasa}

Perjanjian Baru berkisah mengenai pewartaan seputar kehidupan dan karya Yesus Kristus dan para murid-Nya serta "peristiwa-peristiwa yang telah terjadi di antara kita" (Luk 1,1). Kisah-kisah ini menyingkapkan aneka fungsi: kerygma, misioner, liturgi, pastoral, doksologia, etika, dll.

Dalam menyajikan kisah ini, bahasa tulisan Perjanjian Baru berbentuk naratif: kisah seputar mukjizat Allah di dalam diri Yesus dan Gereja-Nya.

$<<$ Awal dari setiap Teologi Biblis berbentuk narasi. Allah menyingkapkan diri-Nya di dalam dan melalui peristiwa sejarah, bukan dalam peristiwa aksidental (kebetulan) yang dipandang sebagai bagian umum dari sejarah sebagaimana tertuang dalam buku-buku pertama dari kanon Perjanjian Lama dan buku terakhir Perjanjian Baru. Di dalam buku-buku tersebut dimasukan refleksi-refleksi teologis yang bernuansa prediksi ke masa depan dengan mempergunakan sebuah narasi yang menakjubkan tentang karya Allah dan kesaksian akan sejarah dan pengalaman keselamatan dari pihak manusia>>. 6

${ }^{5}$ Enrico dal Cavolo (ed), Storia della Teologia dalle Origini a Bernardo di Chiaravalle, 1a, Edizione Dehoniane, Roma 1995, hlm. 41.

${ }^{6}$ Enrico dal Cavolo (ed), Storia della Teologia..., 43. 
Bagian tertua dari tulisan Perjanjian Baru tidak diawali dengan hantaran filosofis atau teologis, tetapi dilukiskan dalam narasi sederhana mengenai kenyataan hidup Yesus yang berkeliling untuk berbuat baik (berkarya), wafat di salib, dimakamkan dan bangkit pada hari yang ketiga. Kisah ini dilanjutkan dengan inti cerita seputar aktivitas (karya) hidup Yesus sebelum kematian-Nya (Kis 2,22; 10,3639). Hal yang sama juga ditemukan dalam awal kotbah Petrus pada peristiwa Pentakosta berkenaan dengan pengalaman aktual yang mereka alami.

$<<$ Kusampaikan kepadamu, yaitu apa yang telah kuterima sendiri, ialah bahwa Kristus telah mati karena dosa-dosa kita >> (I Kor 15,3), "Allah membangkitkan Dia (I Tes 1,9) ... Kutipankutipan Kitab Suci, dalam Kisah Para Rasul, memperlihatkan sebuah bentuk penafsiran teologis mengenai semua kenyataan dengan meneropong kembali kisah-kisah dalam sejarah keselamatan, namun hanya terhenti pada peristiwa-peristiwa yang terjadi dalam sejarah itu sendiri. Sastra umum yang dipergunakan Markus dalam bentuk "pewartaan" merupakan perluasan dari elemen-elemen naratif yang berkenaan dengan dimensi pemakluman itu sendiri. Gereja mendaftar dan menetapkan pelbagai kisah pewartaan seputar kehidupan dan karya Yesus ini berdasarkan bentuk sastra umum, "kata-kata (perkataan) kebijaksanaan" (Q) untuk menghindari bahaya penyempitan atau pereduksian peristiwa hidup Yesus ke dalam doktrin yang bertolak-belakang dengan fakta sejarah dan mendekati doketisme gnostik >>.7

Yohanes dan Paulus menyingkapkan beberapa kecemasan teologis berkenaan dengan aneka persoalan iman yang muncul di kalangan umat. Untuk itu, mereka memaparkan aneka jawaban yang tegas atas persoalan yang dihadapi serta mencanangkan strategi yang tepat untuk memperkuat dan memperdalam iman umat dengan menggunakan bahasa yang tegas, pasti dan jelas disertai alasan yang mendalam berdasarkan fakta yang terjadi dalam sejarah keselamatan. Mereka merumuskan inti iman yang benar bagi komunitas Kristen dengan memadukan semua ajaran Kitab Suci.

${ }^{7}$ Enrico dal Cavolo (ed), Storia della Teologia..., 44. 
Menyimak kenyataan ini, maka dapat ditegaskan bahwa melalui kisah seputar hidup dan karya Yesus ini, penulis Perjanjian Baru tidak berteologi. Dengan menggunakan bahasa yang tidak teratur, mereka hanya menyatakan inti kebenaran iman mengenai Wahyu Allah dalam diri Yesus. Inti wahyu Allah dalam diri Yesus Kristus inilah yang menjadi unsur hakiki dan landasan fundamental dalam keseluruhan teologi.

Bahasa yang dipergunakan oleh Yohanes dan Paulus ketika berbicara mengenai Allah yang hadir dalam diri Yesus Kristus, Gereja, Sakramen, Keselamatan, dan lain-lainnya memperlihatkan bahwa mereka memiliki cakrawala "pengetahuan teologis yang luas, mendalam dan melampaui tataran bahasa naratif". Mereka mempergunakan bahasa spekulatif dengan memadukan pelbagai konsep dan aneka alasan teologis di setiap momen pewartaan mereka. Dengan cara demikian, mereka masuk ke dalam bahasa kristiani yang bernuansa teologis seperti logos, aletheia, nomos, dikaiosune, morphé, dll. Sejarah Yesus yang dilukiskan dalam bentuk "narasi" (Injil) diubah secara perlahan dari kisah biasa menjadi sebuah kristologi.

Argumen Teologis (alasan kemurtadan Israel-pilihan terhadap orang benar; membuktikan bahwa Yesus sungguh-sungguh Allah dan Manusia; menggunakan Tradisi-paradoks)

Dalam karya Yohanes dan Paulus dijelaskan bahwa Wahyu Original Allah memiliki cakupan teologis yang sangat luas, bukan hanya dalam tataran linguistik, melainkan juga dalam argumen pembuktian yang adekuat, terutama dengan memaparkan fakta-fakta yang sederhana, nyata dan aktual. Bukti-bukti yang dibentangkan bukanlah kisah belaka, melainkan juga berbentuk argumen yang benar, nyata dan dipertanggungjawabkan.

Yohanes dan Paulus menyelidiki alasan "kemurtatan Israel" dan "pilihan yang ditujukan kepada orang-orang benar" serta menemukan dasar pembenaran akibat ketidaksetiaan manusia melalui ketidaksetiaan Israel. Mereka juga memaparkan pelbagai bentuk alasan untuk membuktikan pembenaran Allah dalam diri Yesus Kristus sebagai puncak pemenuhan keselamatan semua manusia: "Yesus Kristus bukanlah manusia biasa, melainkan Putera Allah yang mejelma menjadi manusia. Di dalam Dia, kita menemukan inti kristologi yang sangat berharga" sebagaimana ditegaskan dalam Prolog Injil Yohanes 
dan madah pujian kepada Kristus yang dituliskan Paulus kepada umat di Efesus (1,3-23), Kolose (1,12-20) dan Filipi (2,5-11).

Untuk membuktikan keotentikkan figur Yesus, karya dan inti warta-Nya, para penulis Perjanjian Baru menghantar kita untuk menemukan sendi-sendiri teologis selanjutnya, yaitu argumen-argumen biblis. Mereka merangkum teks-teks Kitab Suci yang berkisah mengenai peristiwa kehidupan Yesus dengan mendasarkan diri pada sastra umum yang oleh Rendall-Harris dan C. H. Dodd disebut kesaksian. ${ }^{8}$ Bertitik-tolak dari peristiwa eskatologi kebangkitan Yesus Kristus dan kelahiran Gereja dalam kekuatan Roh Kudus, mereka membaca kembali naskah-naskah Kitab Suci dengan berpegang pada prinsip yang dipegang teguh oleh para Bapa Gereja:

$<<$ Penggunaan dan pendasaran kuat pada Kitab Perjanjian Lama ditemukan dalam Kitab Wahyu. Walaupun penulis tidak menggunakan kutipan langsung, tetapi dalam bentuk kiasan, namun harta terindah dari Kitab Perjanjian Lama dijadikan rujukan utama untuk diaplikasikan ke dalam perjalanan sejarah serta diproyeksikan sebagai model di setiap zaman Gereja>>.9

Pengarang Perjanjian Baru memperlihatkan bukti-bukti dari Tradisi dalam setiap argumen teologis mereka. Di dalam Kitab Perjanjian Baru perkataan-perkataan Yunani, seperti paradosis (paradox, sesuatu yang tidak masuk akal, tetapi mengandung kebenaran) dipergunakan secara tepat untuk melukiskan kesaksian apostolik mengenai Yesus Kristus dan konsekuensi yang harus diterima bagi setiap orang yang mengimani ajaran Kristiani (Lk 1,2; II Pet 2,21, Rom $6,17)$. $<<$ Makna hakiki yang terkuak adalah penyerahan total kepada Kristus ...>>. Argumen-argumen dari Tradisi Gereja menduduki tempat penting dalam surat-surat Paulus.

Rasul para bangsa manusia ini bukanlah saksi mata langsung atas setiap peristiwa dan jejak kemanusiaan Yesus, Putera Allah sehingga seluruh ajarannya harus didasarkan pada Tradisi Gereja. Dia menjadikan "Peristiwa Perjamuan Malam Tuhan" dan "Kebangkitan

${ }^{8}$ J. Renddal-Harris - V. Burch, Testimone, Cambridge I, 1916 e II, 1920; C.H. Dodd, According to the Scriptures, London 1952.

${ }^{9}$ Enrico dal Cavolo (ed), Storia della Teologia..., 57; bdk. Grech, Eemenutica dell'Antico Testamento nel Nuovo, Roma 1989. 
Kristus" sebagai titik kunci untuk memahami kemanusiaan dan keAllah-an Yesus. Di dalam suratnya kepada jemaat di Korintus, dia menuliskan: <<Sebab apa yang telah kuteruskan kepadamu, telah aku terima dari Tuhan, yaitu bahwa Tuhan Yesus, pada malam waktu Ia diserahkan...>> [...] <<Sebab yang sangat penting telah kusampaikan kepadamu, yaitu apa yang telah kuterima sendiri, ialah bahwa Kristus telah mati karena dosa-dosa kita, sesuai dengan Kitab Suci>> (I Kor $11,23 ; 15,3)$.

Melalui pernyataan ini, dia tidak hanya menegaskan keyakinan imannya dengan mengutip tradisi sebelumnya, melainkan memperlihatkan mutu tradisi iman di dalam argumen teologis yang tertuang dalam surat-surat pastoralnya. Tradisi menyingkapkan ciri doktrinal dari ajaran iman dan obyek iman yang harus dipegang secara integral dan penuh kesetiaan. Karena itu, dia menitipkan pesannya kepada Timoteus untuk <<memelihara harta yang indah, yang telah dipercayakan-Nya>> (II Tim 1,14), baik segala sesuatu yang telah didengar dari setiap pewartaan lisan ( II Tim 1,13) maupun yang berasal dari Kitab Suci (II Tim 1, 18; 4,11). $<<$ Surat-surat pastoral ditulis untuk meneguhkan kecemasan kaum beriman; menjamin keaslian Tradisi Apostolik serta karya pelanyanan yang diteguhkan melalui penumpangan tangan $>>.10$

Berbeda dengan Paulus, di dalam suratnya, Petrus justru menegaskan sikapnya kepada kaum beriman untuk tidak mengutip Kitab Perjanjian Lama sehingga setiap pribadi diberi peluang untuk menafsir sesuai dengan tuntutan konkrit (I Pet 1, 20). Apabila dijejaki secara cermat penegasan Petrus ini, maka ditemukan landasan berpikir yang bersifat paradox. Satu hal mendasar yang ingin ditegaskan Petrus adalah: <<tanggung-jawab tertinggi untuk meneruskan dan menjelaskan kenyataan iman yang paradoxal ini tidak tergantung pada kuasa manusia, melainkan pada kuasa Tuhan dan Roh Kebenaran, yaitu Roh-Nya sendiri (Yoh 14,16). Berkat kekuatan ini, maka akan terpenuhi di masa yang akan datang setiap bentuk paradoks $>>.11$

\footnotetext{
${ }^{10}$ F. Arduso, "Tradizione", ini Nuovo Dizionario di Teologia, Roma 1977, 1771.

${ }^{11}$ L. Lengsfedi, “Tradizione e Bibbia. Loro Rapporti”, in, Mysterium Salutis I, Brescia 1967, 397.
} 
Alfonsus Ara, Perjanjian Baru dan Teologi

\section{Kriteria Ortodoksi}

Salah satu fungsi utama dari teologi adalah mengajarkan doktrin resmi Gereja dan mempertahankannya dari serangan kaum heretik. Semenjak Irenius tidak banyak ditemukan tulisan untuk melawan kaum heretik (adversus haeresen). Kecemasan untuk membela dan mempertahankan ortodoksi iman Gereja, hidup dan berkembang pada komunitas Kristen purba dan para penulis Perjanjian Baru, terutama Yohanes dan Paulus. Berawal dari kecemasan ini, mereka menentukan kriteria dasar untuk membedakan ajaran ortodoksi iman dari ajaran kaum heretik yang mencemarkan inti pewartaan dan identitas Gereja.

Terhadap tuntutan yang diberikan kepada umat di Galatia yang sudah beriman (kaum Yahudi-Kristiani yang bertobat dari kekafiran) untuk "disunat dan memperlajari Torah", Paulus menegaskan otoritas apostoliknya ${ }^{12}$ sebagai utusan untuk mewartaan Injil Allah yang sesuai dengan pewahyuan para malaikat (Gal 1,8-9). Untuk itu, Paulus menegaskan kembali pernyataan-pernyataan iman yang tertuang di dalam Kitab Suci (Gal 1,6 = Maz 143,2). Namun, argumen terkuat yang ditegaskan Paulus justru lahir dari inti imannya sendiri kepada Yesus Kristus: <<Aku tidak menolak kasih karunia Allah. Sebab sekiranya ada kebenaran oleh hukum Taurat, maka sia-sialah kematian Kristus $>>$ (Gal 2,21). Keyakinan pribadi Paulus ini diteguhkan kembali dengan argumen imannya yang tertuang di dalam suratnya kepada Umat di Korintus untuk melawan setiap orang yang menolak (tidak percaya) kepada peristiwa "Kebangkitan Yesus": <<Tetapi andaikata Kristus tidak dibangkitkan, maka sia-sialah pemberiataan kami dan sia-sialah juga kepercayaan kamu>> (I Kor 15,14).

Di setiap surat pastoralnya, kriteria utama ortodoksi iman yang ditetapkan Paulus adalah "Tradisi". Walaupun demikian, Paulus selalu menegaskan relasi penting yang tidak pernah boleh diabaikan antara lex orandi (hukum doa) dengan ortopraksis atau lex vivendi (hukum hidup).

Di dalam suratnya, Yohanes menetapkan otoritas Kitab Suci dan Tradisi sebagai kriteria ortodoksi iman. Di samping, Kitab Suci dan Tradisi, Yohanes dan Paulus menetapkan kriteria ortodoksi iman yang

\footnotetext{
12 Otoritas ini diteguhkan melalui sebuah permohonan kepada Konsili di Yerusalem (Gal 2,6-10).
} 
lain, yaitu kharisma untuk menafsirkan dan menilai inti iman. Namun, karisma bukanlah "kriteria mutlak" (absolut) sebab karisma harus taat kepada kebaikan bersama (bonum comune) dan harus ditaati oleh orang-orang yang berpegang pada karisma kebenaran yang pasti, terutama para Rasul.

Mengacu pada uraian di atas, maka dapat disimpulkan bahwa kriteria utama ortodoksi iman di masa Perjanjian Baru adalah Kitab Suci, Tradisi, akal sehat, lex orandi, karya Roh Kudus (karisma), dan ortopraksis (kebaikan moral dan buah-buah iman, terutama kebaikan).

$<<$ Bisa dikatakan bahwa kriteria ortodoksi iman terdiri dari delapan sendi utama yang membentuk kerygma, inti iman, kesaksian Kitab Suci, lex orandi, sensus fidelium, akal sehat, tandatanda Roh Kudus dalam sejarah dan otoritas Apostolik dan Konsili. Sebuah doktrin dinyatakan salah dan heretik apabila menyingkapkan sikap iman pribadi yang bertentangan dengan komunitas kaum beriman, atau tidak sesuai dengan identitas doktrinal yang terdiri dari delapan segi yang sudah ditetapkan $>>.13$

\section{Benih-benih awal Simbol Apostolik}

Berakar pada hasil penelitiannya yang akurat, San Thomas Aquino menegaskan bahwa credo (Simbol Apostolik) merupakan "inti dari summa iman kristiani"; "kartu identitas", "tanda pengenal" dan "identitas asali keanggotaan Gereja". Berkenaan dengan penegasan San Thomas Aquino ini maka akan sangat menarik untuk menyimak inti alasan yang dipaparkan Aquinate untuk membenarkan dan memperlihatkan otentisitas simbol iman tersebut:

$<<$ Simbol iman para Rasul merangkul semua inti kebenaran iman Gereja sehingga mempermudah kaum beriman untuk menerima, memahami dan mengimaninya; tiada seorang pun yang menyangkal dan menjauhkan diri dari inti kebenaran iman tersebut karena dianggap keliru. Rangkuman keputusan ini

${ }^{13}$ Enrico dal Cavolo (ed), Storia della Teologia ..., 80-81. 
Alfonsus Ara, Perjanjian Baru dan Teologi

dengan sendirinya memberikan pendasaran yang kuat pada simbol-simbol iman itu sendiri $>>.14$

Patut diakui bahwa skema awal credo iman Gereja ini merupakan simpulan dari rumusan pengakuan iman yang terkandung di dalam paham-paham teologis kisah-kisah Injili. Dari simpulan rumusan pengakuan iman ini terbentuklah "simbol apostolik", "inti iman kristiani" dan "inti dari semua teologi".

Menyimak sejarah perumusan credo iman Gereja ini, maka dapat ditegaskan bahwa rumusan "pengakuan iman Gereja" yang pertama berkarakter "Kristologis". Unsur pembeda antara skema pengakuan iman bangsa Israel dengan skema pengakuan iman Gereja terletak dalam "inti iman kepada Yesus Kristus. Dia adalah "Musa Baru, Kepenuhan Nubuat Perjanjian Lama; Proklamator Hukum Baru, Mesias dan Putera Allah".

Seluruh tulisan Perjanjian Baru berkarakter Kristologis sebab berkisah tentang Yesus, Putera Allah yang menjelma menjadi dan untuk menyelamatkan manusia". Yesus dari Nazaret diperkenalkan sebagai "Kristus, Mesias, Tuhan, Penyelamat, Putera Manusia"; sedangkan karakter lain menyingkapkan sisi verbal kehidupan Yesus: "Yesus dikenal berdasarkan tindakan dan perbuatan-Nya, terutama pewartaan, kematian dan kebangkitan-Nya: <<karena dosa-dosa kita...untuk membenarkan kita $>$ (Rom 4,24). Dalam Kisah Injil, pengakuan tertinggi terhadap martabat dan kodrat diri Yesus dinyatakan oleh Allah, Bapa-Nya sendiri melalui mulut Petrus: $<<$ Engkaulah Kristus, Putera Allah yang hidup>> (Mat 16,16) dan Pengakuan Thomas: $<<$ Ya Tuhanku dan Allahku $>>($ Yoh 20,28).

Berawal dari pengakuan iman para Rasul yang ditemukan dalam Injil Sinoptik ini, maka dirumuskan inti pengakuan iman yang lebih kaya. Rumusan ini merupakan perpaduan antara konsep teologis yang tertuang di dalam "prolog Injil Yohanes" dengan "Madah kristologis Rasul Paulus". Hasil "perpaduan" ini membentuk "regula fidei" (aturan iman) dan "simbol apostolik".

Itu berarti bahwa "credo" atau "pengakuan iman Gereja" merupakan proses kristalisasi dari konsep-konsep iman kaum beriman

${ }^{14} \mathrm{~S}$. Thomas D'aquino, Summa Theologia II-II, 1,9. 
kepada Yesus Kristus, Allah yang menjelma menjadi Manusia. $<$ <Mereka mengungkapkan dan mengembangkan inti iman mereka dengan berlandaskan pada pengakuan iman Perjanjian Lama, terutama paham-paham Judaisme dan Helenisme (...). Pengakuan iman Gereja terhadap Pribadi dan Karya Yesus, terutama "kematian dan kebangkitan-Nya untuk kita>> dirumuskan berdasarkan kategori Biblis-Yahudi: "Rumusan ini diolah dalam terang "pengakuan iman Kitab Suci, namun dikembangkan lebih lanjut sebab "pengalaman keselamatan" melampaui "Pengakuan Biblis". Di dalam "Pengakuan Biblis", Yesus diakui sebagai Mesias, Putera Daud (katà, sarka), dan Putera Allah (katà pneuma). Kematian dan kebangkitan-Nya menyingkapkan inti kebenaran iman, yaitu:

$<<$ "Perendahan dan Peninggian" orang-orang benar sebagaimana ditegaskan dalam Mazmur, Ayub dan Yeremia. Namun, pernyataan biblis, "kematian karena dosa kita" berakar dari model Hamba yang Menderita (Yes 53). Kristus adalah Imam Agung menurut skema Kitab Imamat (orang Ibrani); sedangkan gelar Adam Baru yang ditegaskan Paulus (I Kor 15) merujuk pada misi Yesus yang diutus untuk memperbaharui kemanusiaan lama kita dan menciptakan kita menjadi manusia baru yang hidup dalam dan berkat kekuatan Roh. Yesus adalah Allah, Sang Gembala Israel sebagaimana dilukiskan Yohanes; sedangkan dalam Kitab Wahyu disingkapkan seluruh kemuliaan Dia yang meraja dan memerintah sejarah manusia dan juga dalam lingkup Anak Domba Allah yang rela berkorban untuk kita>>. 15

Titik kesamaan yang terkandung dalam "pengakuan biblis" dan "credo" atau "inti pengakuan iman apostolik" ini terletak pada "jawaban otentik (ungkapan visi dan maklumat batin atau cetusan gerakan suara hati manusia) kaum beriman dalam menanggapi dan merangkul inti kebenaran Wahyu Allah dalam diri Yesus Kristus". Namun, keterbukaan dan kemampuan manusia untuk menanggapi Wahyu Allah dalam diri Yesus tidak lahir dari potensi nalar atau alasan-alasan teologis yang disajikan, tetapi berkat kekuatan Rahmat Allah yang memberdayakan keterbatasan nalar manusiawi kita dan pandangan estetik setiap orang yang mengkontemplasikan realitas ilahi yang dimanifestasikan dalam pribadi dan karya Yesus Kristus. Pengakuan iman lahir dari tanggapan kaum beriman atas Wahyu

${ }^{15}$ Enrico dal Cavolo (ed), Storia della Teologia..., 50-51. 
Allah. Landasan ini kelak menjadi sumber original bagi dari setiap permenungan teologis. Beradasarkan kenyataan ini, maka teologi baltasariana membedakan lingkup teologis menjadi: estetika, dramatika dan logika; sedangkan "pengakuan iman" menjadi bagian dari tahapan estetika (dari kemuliaan).

\section{Inkulturasi}

Menurut A. Harnack, para Bapa Gereja dan Konsili-konsili Ekumenis Perdana telah menghancurkan rumusan "Doktrinal Iman Kristiani Helenistik". Penilaian A. Harnack ini didasarkan pada fakta sejarah bahwa pengaruh budaya helenistik yang sudah bergema sejak awal kekristenan tidak dikembangkan atau dipertahankan sebab doktrin Gereja terkungkung seutuhnya dalam kodrat yang satu dan sama yaitu inkarnasi dan katolisitas.

Walaupun demikian, ada satu fakta yang tidak bisa disangkal kebenarannya, yaitu: "Teologi Kristen digali, dibangkitkan dan berkembang dalam lingkup budaya Yahudi dan Yahudi-Romawi, sebab puncak Wahyu Allah dalam Perjanjian Baru terpenuhi melalui peristiwa penjelmaan Logos Kekal Allah menjadi Manusia dalam diri Yesus dari Nazareth dalam lingkup linguistik dan konseptual Yahudi. Proses penjelmaan ini dinamakan inkulturasi. ${ }^{16}$

Proses inkulturasi yang sesungguhnya dinyatakan Yesus sendiri dalam kehidupan, sikap hidup, karya dan inti warta yang disampaikan-Nya. Mencermati proses integrasi dan konkretisasi ini, maka dapat ditegaskan bahwa peristiwa inkarnasi Putera Allah menjadi manusia merupakan "proses inkarnasi Allah dalam budaya manusia".

$<<$ Kristus sendiri, melalui penjelmaan-Nya, menyatukan (membiarkan diri-Nya) dengan dan oleh situasi sosial dan budaya manusia di mana Dia berada dan hidup [...].17 Putera Allah menjadi orang Yahudi di Nazaret, Galilea, berbicara dengan bahasa Aram, harus taat kepada orang tua-Nya yang berbangsa Yahudi; harus ditemani oleh kedua orangtua-Nya ke Bait Kudus Yerusalem, tatkala Dia ditemukan "sedang duduk di

\footnotetext{
${ }^{16}$ Enrico dal Cavolo (ed), Storia della Teologia ..., 51.

${ }^{17}$ Ad Gentes, 10.
} 
antara para guru yang asyik mendengar dan menginterogasiNya" (Luk 2,46). Yesus bertumbuh dan berkembang di antara orang-orang sezaman-Nya di abad I, dalam lingkup budaya (adat-istiadat) Palestina; belajar bertukang dengan orang-orang sezaman-Nya, mencermati dan memahami tabiat para nelayan, petani dan pedagang dalam lingkungan-Nya. Peristiwa dan pribadi yang dinubatkan para nabi Perjanjian Lama sebagai Mesias yang akan datang justru terjadi di sebuah wilayah negara dan di zaman tertentu. Dia diasuh dalam kesalehan Israel, ditempah dan dibentuk oleh Hukum Ilahi dan ajaran para Nabi dalam lingkup pengalaman khusus (istimewa) yang ditetapkan Allah, Bapa-Nya serta dimatangkan dalam Tradisi Spiritual yang sangat mantap, yaitu dalam lingkup profetisme Yahudi. Seperti para nabi yang hidup di zaman-Nya, Yesus adalah "Mulut Allah" yang diutus untuk mengajak manusia ke alam pertobatan. Bentuk pewartaan-Nya sangat unik: "Kata-kata, sastra umum, dan perkembangan gaya bahasa mengingatkan kita akan tipe Elia, terutama bentuk paralelisme biblis, perumpamaan, bentuk paradoks, nasihat, teguran, kebahagiaan dan tindakan-tindakan simbolik. Seluruh kehidupan Yesus menyatu dengan seluruh kehidupan manusia Israel sebagai sebuah bangsa yang memiliki Tradisi Religius; berada bersama mereka untuk mengungkapkan keunikan keterlibatan-Nya dalam sejarah keselamatan umat manusia; yaitu Umat Pilihan Allah dan Tradisi Religius yang memiliki makna yang mapan bagi kehidupan manusia>>.18

Kelanjutan proses inkulturasi Logos Kekal Allah dalam realitas budaya dan sabda manusia berawal dari Yesus dan pelimpahan kekuatan Roh kepada komunitas para Rasul dan Murid-murid-Nya, yaitu Gereja.

$<<$ Pada hari Pentekosta, melalui pencurahan Roh Kudus dimaklumkan hubungan antara iman Kristen dengan budaya manusia sebagai peristiwa kepenuhan: janji keselamatan yang terpenuhi dalam diri Yesus yang bangkit, memenuhi hati kaum beriman dengan daya Roh yang dicurahkan-Nya $>>.19$

18 Dokumen Fede e Inculturazione, dari Commissione Teologica Internazionale (1988), no. 13-15.

${ }^{19}$ Dokumen Fede e Inculturazione..., no. 23. 
Komunitas Kristen perdana yang berasal dari kalangan Yahudi tidak perlu membentuk budaya yang eksklusif (budaya baru) untuk menunjukkan identitas dan jati diri mereka sebagai pengikut Kristus. Kebaruan mereka sebagai pengikut Kristus tidak menanggalkan keYahudi-an mereka. Namun, sebagai pengikut Kristus, mereka harus mengenakan Kristus dan mengakarkan Warta Injil Kristus dalam bahasa, pola pikir, pola sikap, pola tindak dan pola budaya mereka:

$<<$ Gerakan Roh Ilahi membimbing dan menuntun mereka untuk mengakarkan Warta Injili ke dalam bahasa, ritus, adatistiadat, nilai, dan lembaga-lembaga Israel sehingga inti Warta Injili bisa diterima, dimengerti dan diimani sesuai dengan citarasa mereka sendiri>>.

Untuk memenuhi target inkulturasi ini, maka dalam kurun waktu yang cukup lama, Gereja membentuk komunitas kecil di Palestina. Komunitas ini membuka diri terhadap orang-orang yang berkehendak baik dan berkeinginan kuat untuk menjadi "Katolik". Mereka merintis proses inkulturasi baru yang berlandaskan pada model Yunani (helenisme). Sementara itu, pergerakan kaum muda Kristen yang berupaya menunjukkan jati diri mereka sebagai "penganut agama yang benar", baik di hadapan Judaisme maupun kaum kafir, berinisiatif menciptakan "simbolisasi dunia baru" dengan mengubah inti kehidupan agama yang sesungguhnya (agama yang benar berakar dalam realitas batin, bukan penampilan lahiriah).

Beranjak dari wilayah perbatasan di Palestina dan kontak yang mendalam dengan strata sosial kaum Kafir, para pewarta Injil melihat langkah penting yang harus dilakukan, yaitu:

$<<$ memperkenalkan warta Kristiani yang sesuai dengan cita rasa budaya Kafir sehingga mampu diserap dan dimengerti tatkala konsep-konsep Kristiani dipertemukan dengan landasan filosofis, terutama platonis dan stoisisme (transendensi dan kebaikan Allah, fungsi kosmologis Logos, kebebasan manusia, dll) yang sebelumnya dipandang sebagai wawasan politik untuk menciptakan stabilitas hubungan di antara mereka dalam lingkup kafir [..]. Apabila kekristenan ingin menginkulturasikan atau mengakarkan Warta Injil ke dalam budaya kaum kafir sehingga mudah dicerna, dipahami dengan nalar dan sesuai dengan cita rasa mereka, maka tema tersebut 
harus dikembangkan secara adekuat menurut tingkatan problema dan terminologi yang biasa dalam konteks mereka $>>.^{20}$

Paulus dan Yohanes memperlihatkan kebrilianan potensi nalar mereka ketika berusaha mengakarkan Warta Injil Tuhan dan kekayaankekayaan teologis dalam Kitab Suci ke dalam budaya manusia di zaman mereka. Mereka mempergunakan ungkapan-ungkapan yang bernuansa filosofis seperti logos, ousia, morphé, nomos, aletheia, apatheia, airesis, enkrateia, eusebeia, dll supaya bisa di mengerti oleh kaum Yahudi yang berbahasa Yunani. Namun, langkah yang dilalukan Paulus, Yohanes dan penulis Perjanjian Baru lainnya, bukan untuk menginkulturasikan atau mengakarkan "iman kristiani" ke dalam bahasa dan kategori filosofis khusus, terutama ke dalam filsafat plato sebagaimana yang dilakukan oleh seorang Ibrani, Filone, di saat memperlihatkan pertalian yang akurat antara pola pikir Plato dan dunia kekristenan.

Perjanjian Baru bukanlah sebuah filsafat ataupun teologi, melainkan kisah mengenai singkapan Wahyu Allah yang berpuncak dalam diri Yesus dalam setiap peristiwa hidup manusia dan lukisan mengenai makna Sabda Allah sehingga bisa dimengerti dan diimani oleh manusia di setiap lingkup budaya yang berbeda. Oleh karena itu, di dalam lingkungan Kafir, dinilai tidak tepat apabila Wahyu Allah dalam Kitab Suci dijelaskan dengan menggunakan konsep filosofis dan teologis. Perjanjian Baru merupakan sebuah paradoks bagi para murid yang mengenal dan mengimani Yesus sebagai puncak Wahyu Allah, Sang Sabda Kekal yang menjelma menjadi daging $<<$ untuk menghapus dosa-dosa kita >>.

$$
===0000====
$$

${ }^{20}$ M. Simonetti, Cristianesimo e cultura Greca, Roma 1983, 36. 
Alfonsus Ara, Perjanjian Baru dan Teologi

\section{DAFTAR PUSTAKA}

Bultmann, R. Teologia del Nuovo Testamento. Brescia 1985.

Dodd, C. H. La Predicazione apostolica e il suo sviluppo. Brescia 1973.

Cullmann, Oscar. Il Mistero della Redenzione nella Storia. Bologna 1966.

Conzelmann, H. Teologia del Nuovo Testamento. Brescia 1972.

Goppet, L. La Teologia del Nuovo Testamento. Brescia 1982, 1983.

Jeremias, J. Teologia del Nuovo Testamento, I. La Predicazione di Gesù, Brescia 1976.

Segalla, G. Panorama teologico del Nuovo Testamento. Brescia 1987.

Vilanova, E. Storia della teologia cristiana. Borla, Roma. vol I, 1991. vol. II, 1995. In AA. VV. (Istituto Patristico Augustinianum). Stroria della Chiesa. Piemme, Casale Monferrato. vol. I, 1993 \& vol. III, 1994, 28).

Cavolo, Enrico dal (ed). Storia della Teologia dalle Origini a Bernardo di Chiaravalle, 1a. Edizione Dehoniane, Roma 1995. hlm. 41.

Renddal-Harris, J - Burch, V. Testimone, Cambridge I, 1916 e II, 1920.

Dodd, C. H. According to the Scriptures, London 1952.

Grech, Eemenutica dell'Antico Testamento nel Nuovo, Roma 1989.

Arduso, F. “Tradizione”, ini Nuovo Dizionario di Teologia. Roma 1977, 1771.

Lengsfedi, L. "Tradizione e Bibbia. Loro Rapporti", in, Mysterium Salutis I, Brescia 1967, 397.

D'aquino, Thomas. Summa Theologia II-II, 1,9. 
Logos, Jurnal Filsafat-Teologi, Vol. 12, No. 2, Juni 2015

Dokumen Fede e Inculturazione, dari Commissione Teologica Internazionale (1988), no. 13-5.

Simonetti, M. Cristianesimo e cultura Greca. Roma 1983, 36. 